\title{
Death of a Sales Man illuminated that a Resistance of Realism Play
}

\section{T. Poornima}

M.Phil, Scholar, Department of English, Nadar Saras wathi College of Arts and Science, Theni, Tamil Nadu, India

\begin{abstract}
Arthur Miller was a realist. His plays deal with real characters and events. His characters use an idiom of the common man. Their problems relate to every common man of this world. This joys are our own their miseries like those of ours. Miller's realism is based on the observations of life. He studied not merely the environment but the inside of his characters too. His plays are not escape from romanticism either. Miller believes that romanticism was a part and parcel of majority of people. So he favours a synthesis of determinism and a paradox of will. His plays are concerned with the identity of self. Some of them touch upon the generativity also.
\end{abstract}

Keywords - realism, expressionism, techniques, forms and styles.

Arthur miller was an American playwright who came to the scene after the Second World War. He achieved his first success with All My Sons. Since then he has written about nine major plays film script short stories and several critical essays. He has written three novels and few short stories too. More than any other contemporary playwright, he has assumed the mantle of Robert Sherwood as the public conscience of America. He seems to have been concerned with international peace. $\mathrm{He}$ is popular playwright because he has the touch of common speech mingled with democratic idealism, poetic expression, and an ancient people's capacity for understanding the anguish of the soul.

According to Miller, such a force in Greek times may have been called mysterious fate or destiny, in modern times, it was the power of capitalism and the banized valuesystem that tends to regiment and control the life of an average individual. In this dramatic Miller perfects the realistic mode which he thinks was the most suitable to depict the kind of themes he was interested in. This, however, has not stopped him from experimenting with various expressionistic techniques, as was evident in his plays like Death of a Salesman and After the Fall. Also, Miller writes in a language that was simple direct, forceful and dramatic, although a little prosaic.
Miller accepts conventional realism, but at the same time he does not ignore the inner workings of human psyche and mind. In his introduction to the collected playshe hints at his involvement with the three stylistic modes prevalent in modern drama the realistic, the expressionistic, and the rhetorical. "I have stood squarely in conventional realism", he declares acknowledging Ibsen's impact on himself. Although he had gained appreciation for the power of 'hard facts' from Dostoevsky's The Brother Karamazov, he learned how 'to make the moral world-real and evident' by observing in his plays as in Ibsen's was never stated out revealed in terms of hard actions, irrevocable deeds.

Miller expanded realism in two directions. From the start of his wished to enrich the realistic style with 'an evaluation of life' a conscious articulation of ethical judgment. Quite early that wish led to a vending predicament. In The Man Who All the Luck he realized soon after completing the work, had not been able to avoid a rhetorical, or discursive presentation of his theme. With the next play he determined to 'forego' any sentiments that did not arise naturally from the actions. The plan in All My Sons was "to seek cause and effect, hard actions, facts, the geometry of relationships, and to hold back any tendency to express an idea in itself unless it was literally forced out of a character's mouth". In this way Miller though he would find it possible to elicit a "relatively sharp definition of the social aspects" without going back to the discursiveness of the earlier play.

Arthur Miller's Death of a Salesman presents a realistic evaluation of American values. Its realism was fairly obvious, and reflects the influence on Miller of Ibsen, the great realist reformer. Other realists may satisfy themselves by just observing and depicting the reality, but Miller goes beyond that. If there was an evil, he hits at it with a reformer's zeal.

In All My Sons and Death of a Salesman Miller adopts Ibsen's "retrospective" structure in which an explosive situation was both explained and brought to a crisis by the gradual relation of some-thing which has 
happened in the past. In Death of a Salesman this was of course, Willy Loman's adultery, which by alienating his son, Biff, has destroyed the strongest value in Willy's life. This structure was filled out with a detailed evocation of modern, urban, lower- middle-class life: Miller documents a world of arch-supporters, aspirin, spectacles, subways, time payments, advertising, Cheverolets, faulty refrigerators, life insurance, mortgages, and the adulation of high school football heroes. The language, too except in a few places was an accurate record of the grouping, half inarticulate, cliche-ridden inadequacy of ordinary American speech. And the deadly realism of the picture was confirmed for us by the way that American audiences have immediately recognized and identified with it in the theatre.

But Miller does not remain content with surface realism only. He tries to project it unto symbolism in Death of a Salesman as well as in others plays. Consider, for instance, the value that Willy and his sons attach to manual work, and its glamorous extension, sport, their belief that it was necessary for a man keep fit, to be able to handle tools and build things. Willy's handiness around the house was constantly impressed on us: "He was always good with his hands". Linda remembers, and Biff says that his father put more enthusiasm into building the stoop than into all his salesman-ship; in his reveries Willy again teaches his boys how to simonize a car the most efficient way, and was contemptuous of his neighbour Charlie's son Bernard, because they lack the manual skills. Willy's favourite son Biff, was even more dexterous than his father in high school he was a star athlete and as a man, he can find happiness only as a ranch hand one remembers that Willy's father was a pioneer type who drove over the country in a wagon, earning money by ingenious inventions and the making of flutes. Willy's mystique of the physical skill was thus a reflection of the simpler, pioneer life he craves, a symptom and a symbol of his revolt against the constraints of the modern city.

Slightly more abstracts, yet still realistic was the play's use of trees to symbolize the rural way of life which modern commercialism is choking. Willy, we are told, bought his house originally because it stood in a wooded suburb where he would hunt a little, and where his yard was flanked by two great elms; but now the trees have been cut down and his property was so over. Shadowed by apartment houses that he cannot even grow seed in his back garden. We learn at the beginning that it was dreaming about the countryside and watching scenery, particularly trees, which was the main cause of Willy's recent road accidents; it was so looking after timber that Willy's brother Ben, tries to persuade him to go to Alaska; the "Jungle". Ben says was the place for riches and at moments of crisis. Willy tells "The woods are burning", a phrase which is nonsensical unless seen in context of the other tree references.

The last example already diverging from realism; that was it was not a phrase habitually used in American life; it needs the context of the play to give it meaning. And when we find miller directing that whenever Willy remembers the past, the stage be drenched in a green, checkered pattern of leaves, then it was an obvious that the technique has moved realistic symbolism to outrightexpressionism. There are symbolic and expressionistic leanings in the setting too. The apartment silhouettes are bathed in angry orange; when Willy remembers the past the house was dapped by the green of vanished trees; when Biff and Hap pick up two women and neglect their father, the directions request a lurid red; and at the end, when Willy insanely thesis to plant seed by night, the "blues" of the stage direction simultaneously suggest moonlight and his mood of despair.

Music was similarly manipulated: the rural way of life was represented by flute music, telling "of grass of the life he should have led or of the early days when his suburb was still in the country. It was associated with Willy's pioneer father, the flute maker; and in the world has degenerated to willy and Biff's un business like to habit of whistling in elevators, and at a yet further remove, to the mechanized whistling of Howard and his children as played back on a tape recorded.

The tape recorder scene was in fact a brilliantly compact piece of symbolism functioning like the "mirror scene" in some of Shakespeare's plays to epitomize the action of the whole play. Not only does it illustrate the mechanization of family like, but Howard's idolizing of his children and bullying of his wife exactly parallel. Willy's showing a resemblance between the two men which undercuts left wing cliches about employer and worker and when Willy knocks it over and cannot stop it, the machine serves a both cause and illustration of Willy's mental breakdown he has one of his schizophrenic attacks and the mechanical voices, so like those of his own home life, are an equivalent to the clamorous subconscious of which he has also lost control.

The presentation of Ben was an important clue as to exactly how, and why, Miller was using expressionism in Death of a Salesman. Ben is distinct of less real than the order characters of the play. He was not so much a person as the embodiment to Willy's desire for escape and success. Willy calls his "success incarnate." He represents a side of 
Willy's own mind. That was why, Ben appears exactly when Willy thinks of him, which was not true other characters in the memory scenes.

Miller was not using expressionistic techniques in the way they were used by the German writers of the 1920 's, to dramatize abstract forces in politics or economics or history. He was using the technique solely as a means of revealing the character of Willy Loman, the combines realism and expressionism because such a combination reflects the protagonist's actual way of thinking.

\section{REFERENCES}

[1] Arthur Miller's DEATH OF A SALESMAN Published by Lakshmi Narayan Agarwal Educational publishers.

[2] https://study.com/academy/les son/realismexpres sionis m-in-death-of-a-s ales man.html.

[3] https://www.enotes.com/homework-help/wite-aboutsocial-realism-death-sales man-265088 